\title{
Population Dynamics of Horse Mackerel (Trachurus Mediterraneus Ponticus) in the Bulgarian Black Sea Coast
}

\author{
Maria Yankova \\ Department of Marine Ecology and Biology, Institute of Oceanology, Bulgarian Academy of Sciences, 9000 Varna, Bulgaria \\ Correspondence should be addressed to Maria Yankova; maria_y@abv.bg
}

Received 22 January 2013; Accepted 17 February 2013

Academic Editors: A. Arslan, L. Kaczmarek, I. Krams, A. Robins, and C. P. Wheater

Copyright ( 2013 Maria Yankova. This is an open access article distributed under the Creative Commons Attribution License, which permits unrestricted use, distribution, and reproduction in any medium, provided the original work is properly cited.

\begin{abstract}
The horse mackerel Trachurus mediterraneus is a commercially important pelagic fish species in the Black Sea fishery. The present investigation was carried out between May and December 2010 along the Bulgarian coast of the Black Sea. Population parameters of horse mackerel from the trawl and fishing nets catches were estimated from length frequency data, by using ELEFAN-I computer program. The ELEFAN-I analysis gave the following Von Bertalanffy Growth Function (VBGF) parameters: the asymptotic length $\left(L_{\infty}\right)=19.95 \mathrm{~cm}$, growth coefficient value was $k=0.640$, and the hypothetical age at which length is zero was $t_{0}=-0.548$. Based on these growth parameters, the total mortality coefficient $(Z)$ during the study period was estimated to be 2.99 . The estimated value for natural mortality $(M)$ was 1.08 ; hence, the fishing mortality coefficient $(F)$ was 1.91 . The estimated value for the exploitation rate $(E)$ using the length converted catch curve was 0.64 . The estimated sizes of T. mediterraneus at 25,50 , and 75 percent probabilities of capture were $16.80 \mathrm{~cm}, 18.72 \mathrm{~cm}$, and $20.64 \mathrm{~cm}$, respectively.
\end{abstract}

\section{Introduction}

Family Carangidae in the Black Sea is represented by Trachurus trachurus and Trachurus mediterraneus ponticus. In the Bulgarian Black Sea territorial waters, only Trachurus mediterraneus ponticus is present. Entering of separate Trachurus trachurus specimens to the Black Sea from the Sea of Marmara is a quite rare phenomenon [1]. The systematic situation of the Black Sea mackerel was carefully examined by [24]. The same author stated that in the Black Sea, the species was represented by four local subpopulations: the south western (Bosporic), the northern (Crimean), the eastern (Caucasian) and the southern (Anatolian) each one with its own biological characteristics such as wintering grounds, fat content, spawning patterns, age composition, growth rate, feeding patterns.

On the basis of investigation carried out by $[5,6]$ on size composition and also tagging experiments of horse mackerel caught off the Bulgarian coast, they concluded that in the Black Sea, two subpopulations occur that belong to the small size-type of Trachurus mediterraneus ponticus, the eastern and western ones, respectively. According to the same authors, the Black Sea horse mackerel represents a single population, as the environmental conditions are almost one and the same in the whole inhabited area and there exists no positive evidence for the occurrence of two distinct subpopulations differing substantially in their biological parameters. Other authors using electrophoresis methods assume that no difference at species level can be found between $T$. mediterraneus ponticus and T. m. mediterraneus [7]. For this reason according to [8] the large size type occurrence can be explained as a result of heterosis effect between the aforementioned subspecies. This type being sterile does not produce further offspring and becomes extinct after completing its life span [9]. Examination of age and growth is very important in ichthyologic investigations, because fish growth is one of the four main factors (recruitment, natural mortality coefficient, and fishing mortality coefficient) determining stock condition [10]. Population parameters and growth of horse mackerel were investigated by $[9,11,12]$. Population parameters such as asymptotic length $L_{\infty}$ and growth coefficient $k$, mortality (natural and fishing) rate, and exploitation level $E$ were studied with the major objective of rational management and resource conservation $[13,14]$. 


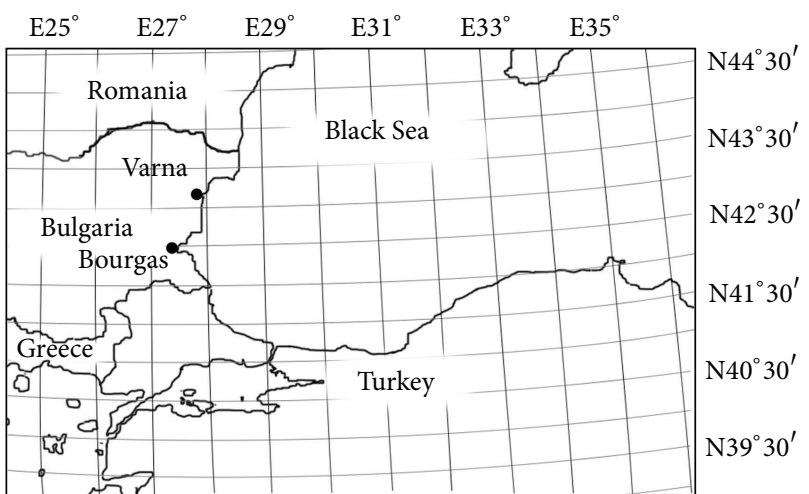

FIGURE 1: Map of area investigated showing the sampling location (modified after Yankova, et al. 2010) [34].

The goal of the present paper is to establish the population parameters of horse mackerel and to determine its natural mortality coefficient value for the investigated period.

\section{Materials and Methods}

Length frequency data of $T$. mediterraneus were collected from trawl and fishing net catches in the Bulgarian Black Sea territorial waters (Figure 1) during the period May 2010 to December 2010. A total of 3400 fish were collected throughout the study period.

Monthly length frequency distributions of T. mediterraneus for each month were analyzed using the Compleat ELEFAN I computer program [15]. The program was also used to estimate the parameters of the Von Bertalanffy growth equation:

$$
L_{t}=L_{\infty}\left\{1-\exp \left(-k\left(t-t_{0}\right)+S_{t}-S_{t_{0}}\right)\right\}
$$

where

$$
\begin{aligned}
& S_{t}=\left(\frac{C K}{2 \pi}\right) \sin \left(2 \pi\left(t-t_{s}\right)\right), \\
& S_{t_{0}}=\left(\frac{C K}{2 \pi}\right) \sin \left(2 \pi\left(t_{0}-t_{s}\right)\right) .
\end{aligned}
$$

For the seasonal Von Bertalanffy Growth Function (VBGF), $L_{t}$ is the length at time $t, L_{\infty}$ the asymptotic total length $(\mathrm{cm}), k$ the growth coefficient (year ${ }^{-1}$ ), and $t_{0}$ the age of fish at zero length (year). The ELEFAN I estimates only two of the three growth parameters $\left(L_{\infty}\right.$ and $k$ ); thus, we computed the third parameter $\left(t_{0}\right)$ by the empirical equation for growth fitting:

$$
\begin{aligned}
& \log \left(-t_{0}\right) \\
& \quad=(-0.3922)-0.2752 \log L_{\infty}-1.038 \log k
\end{aligned}
$$

(see [16]). The growth performance of T. mediterraneus was compared using the index

$$
\phi=\log k+2 \log L_{\infty}
$$

(see [17]). Longevity was calculated from the equation $t_{\max }=$ $3 / k[18]$.

The instantaneous total mortality coefficient $(Z)$ was estimated using the length converted catch curve method which has been incorporated into the Compleat ELEFAN I computer program [15]. Natural mortality $(M)$ was estimated by empirical formula; that is,

$$
\begin{aligned}
\log (M)= & (-0.0066)-0.279 \log \left(L_{\infty}\right) \\
& +0.6543 \log (k)+0.4634 \log (T)
\end{aligned}
$$

(see [19]), where $L_{\infty}$ is expressed in $\mathrm{cm}$ (total length) and $T$ $\left({ }^{\circ} \mathrm{C}\right)$ is the mean annual environmental temperature (it was taken at $\left.14^{\circ} \mathrm{C}\right)$. The exploitation rate $(E)$ was computed using expression

$$
E=\frac{F}{Z}
$$

(see [19]). The recruitment pattern was also derived using the Compleat ELEFAN I computer program [15]. The probability of capture was estimated by backwards extrapolation of the descending limb of the length-converted catch curve. A selectivity curve was generated using linear regression fitted to the ascending data points from a plot of the probability of capture against length, which was used to derive values of the lengths at capture at probabilities of $0.25\left(L_{25}\right), 0.5\left(L_{50}\right)$, and $0.75\left(L_{75}\right)$. The relative yield-per-recruit $\left(Y^{\prime} / R\right)$ was estimated using the knife-edge method of Beverton and Holt model (1957) [20] as follows

$$
\begin{aligned}
\frac{Y^{\prime}}{R}=E U^{M / k}[1 & -\left(\frac{3 U}{1}+m\right) \\
& \left.+\left(\frac{3 U^{2}}{1}+2 m\right)+\left(\frac{U^{3}}{1}+3 m\right)\right],
\end{aligned}
$$

where

$$
\begin{aligned}
& m=\frac{(1-E)}{(M / k)}=\frac{k}{Z}, \\
& U=1-\left(\frac{L_{c}}{L_{\infty}}\right), \\
& E=\frac{F}{Z} .
\end{aligned}
$$

\section{Results and Discussion}

The length range obtained in the horse mackerel was 8 to $19 \mathrm{~cm}$, the majority of the catch being between 12 and $16 \mathrm{~cm}$. The length frequency distribution of T. mediterraneus for the study period is shown in Figure 2. The ELEFAN-I analysis gave the following VBGF parameters: $L_{\infty}=19.95 \mathrm{~cm}, k=$ 0.640 , and $t_{0}=-0.548$. The Powell-Wetherall plots are shown in Figure 3. The corresponding estimates of $L_{\infty}$ and $Z / K$ for T. mediterraneus are $19.73 \mathrm{~cm}$ and 2.35 respectively. This additional estimate of $L_{\infty}$ is slightly smaller than the one estimated through ELEFAN-I. 
TABLE 1: Various growth parameter estimates of T. mediterraneus along the Bulgarian coast.

\begin{tabular}{lcccccc}
\hline$L_{\infty}(\mathrm{cm})$ & $K$ & $t_{0}$ & $t_{\max }$ & Method & $\phi$ & Locality \\
\hline 19.25 & 0.35 & -0.59 & $8.57^{1}$ & Otolith & 2.113 & Bulgarian coast [9] \\
19.99 & 0.31 & -0.49 & $9.67^{1}$ & Otolith & 2.093 & Bulgarian coast [32] \\
19.99 & 0.34 & -0.46 & $8.82^{1}$ & Otolith & 2.134 & Bulgarian coast [31] \\
20.00 & 0.24 & -0.98 & $12.5^{1}$ & Otolith & 1.975 & Bulgarian coast [31] \\
19.45 & 0.23 & -0.93 & $13.04^{1}$ & Otolith & 2.031 & Bulgarian coast [31] \\
19.99 & 0.33 & -0.29 & $9.09^{1}$ & Otolith & 2.077 & Bulgarian coast [31] \\
20.00 & 0.28 & -0.81 & $10.7^{1}$ & Otolith & 1.739 & Bulgarian coast [31] \\
17.55 & 0.45 & -0.19 & $6.66^{1}$ & Otolith & 2.142 & Bulgarian coast [33] \\
18.78 & 0.34 & -0.82 & $8.82^{1}$ & Otolith & 2.079 & Bulgarian coast [34] \\
19.95 & 0.64 & -0.55 & $4.7^{1}$ & ELEFAN I & 2.406 & Bulgarian coast ${ }^{2}$ \\
\hline
\end{tabular}

${ }^{1}$ Based on the Taylor's [17] assumption that $t_{\max }=3 / k$.

${ }^{2}$ Present study.

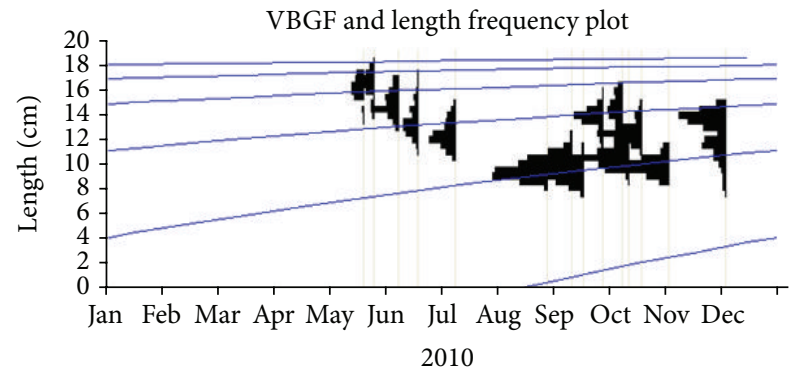

Figure 2: VBG curve of T. mediterraneus with normal length frequency histograms. Lines superimposed on the histograms link successive peaks of growing cohorts as extrapolated by the model.

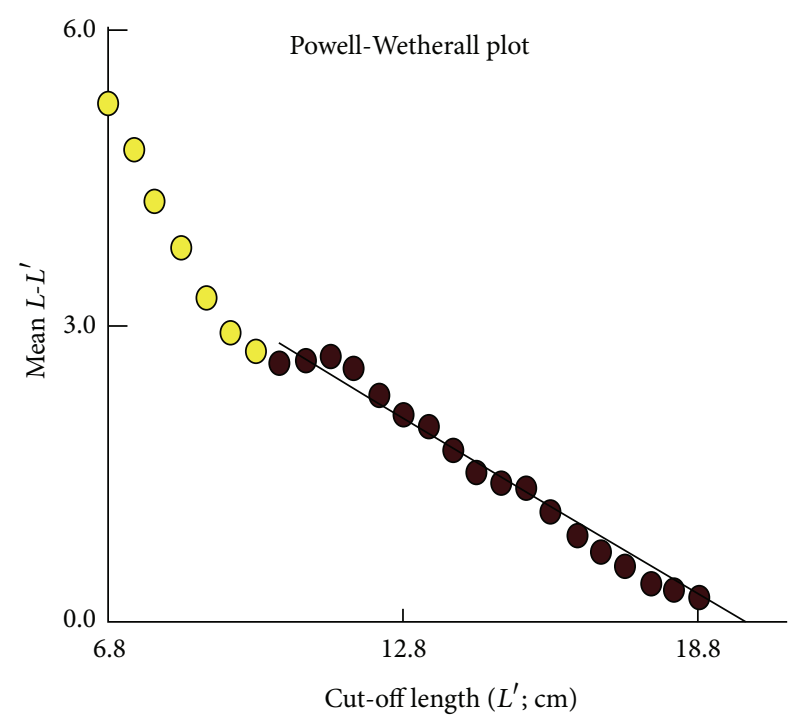

Figure 3: Powell-Wetherall plot of T. mediterraneus $\left(L_{\infty}=19.73 \mathrm{~cm}\right.$ and $Z / K=2.354$ ).

Total mortality based on length converted catch curve gave a value of $Z=2.99$ (intercept-a: 15.020, slopeb: -2.941 , correlation coefficient $r:-0.9985, r^{2}: 0.9969, n$ : 3 , confidence interval of $Z:-5.009-0.873$ ) (Figure 4). Our

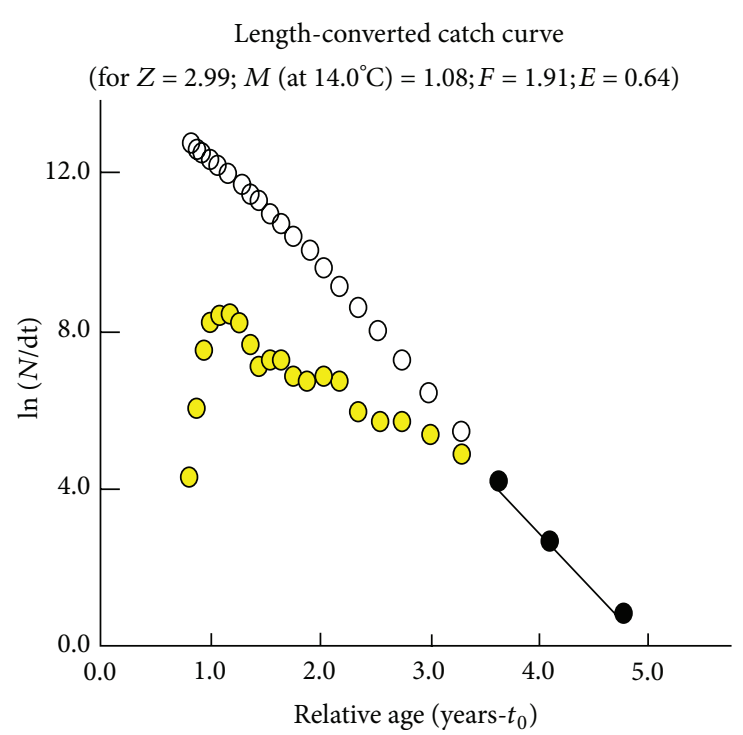

FIGURE 4: Linearized length-converted catch curve for T. mediterraneus caught in Bulgarian Black Sea coast. Dark circles in the figure represent the points used in calculating $(Z)$ through least squares regression lines. The yellow circles represent frequencies of fishes either not fully recruited or approaching $\left(L_{\infty}\right)$ and, hence, discarded from the calculation. The expected frequencies of not fully recruited fishes are added as blank circles.

estimated natural mortality coefficient was $M=1.08$. The reliability of the estimated $M$ was ascertained using the $M / K$ ratio, which has been reported to be within the range of 1.122.5 for most fishes [21]. The $M / K$ ratio $(M / K=1.69)$ in this study falls within the acceptable defined range. The value for exploitation rate $(E)$ calculated in the present study was $E=0.64$. This suggests that during the study period, the stock of T. mediterraneus in the investigated area is under high fishing pressure. The values for instantaneous total mortality coefficient $(Z)$, natural mortality coefficient $(M)$, fishing mortality coefficient $(F)$, and the exploitation rate $(E)$ calculated were $2.99,1.08,1.91$, and 0.64 , respectively. The 


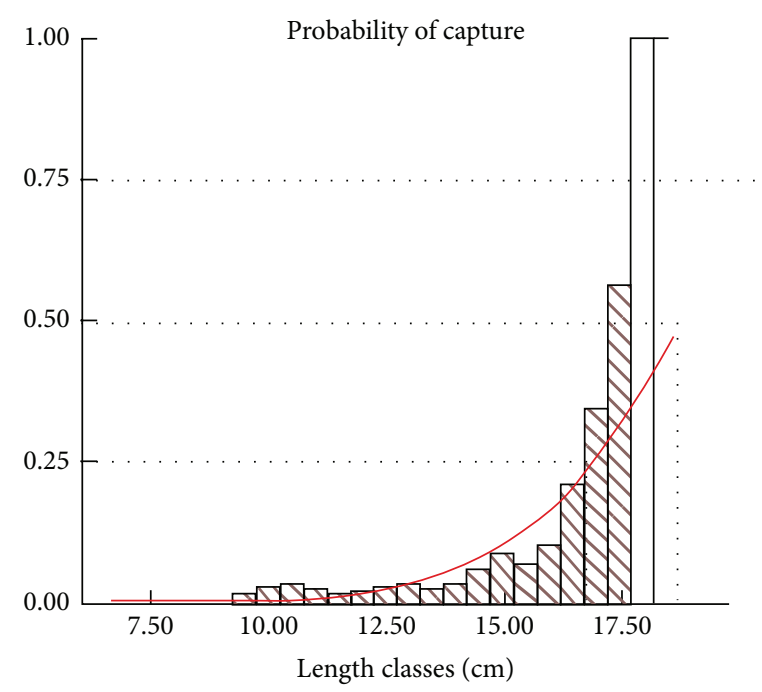

FIGURE 5: Probabilities of capture pattern of horse mackerel.

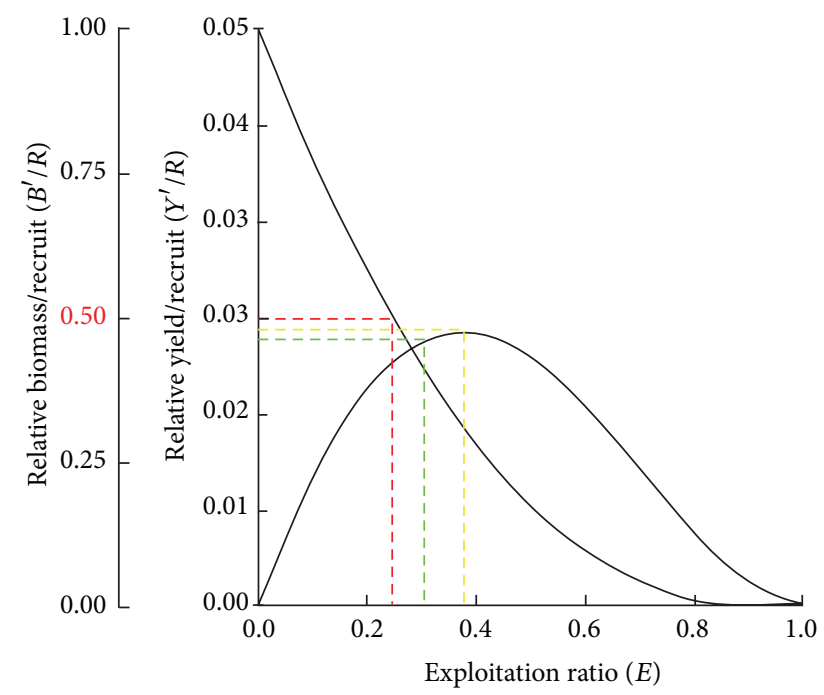

FIgURE 6: The relative yield plot of T. mediterraneus in the Bulgarian Black Sea coast. Yellow line: $E_{\max }$; red line: $E_{50}$; green line: $E_{10}$.

mean length at first capture, $L_{c}$ or $L_{50}$, was $18.72 \mathrm{~cm}$ (TL), and the lengths at capture at probabilities of $0.25\left(L_{25}\right)$ and $0.75\left(L_{75}\right)$ were 16.80 and $20.64 \mathrm{~cm}(\mathrm{TL})$, respectively (Figure $5)$. The relative yield-per-recruit $\left(Y^{\prime} / R\right)$ was determined as a function of $M / K$ (Figure 6). The exploitation rate of population obtained in this study exceeded the maximum allowable limit based on yield-per-recruit calculation $\left(E_{\max }\right)$ which was 0.38 year $^{-1 .}$ Results of the analysis of the recruitment pattern of $T$. mediterraneus during theinvestigation are shown in Figure 7. The recruitment pattern showed one annual pulse of recruitment for horse mackerel (around June). This pulse produced $23.86 \%$ of the recruits. Our asymptotic length value compares favourably with those obtained by others researchers (Table 1). Horse mackerel is a species with a relatively long lifespan, but at the present study age groups of 5 and 6 were completely absent. If one assumes that longevity

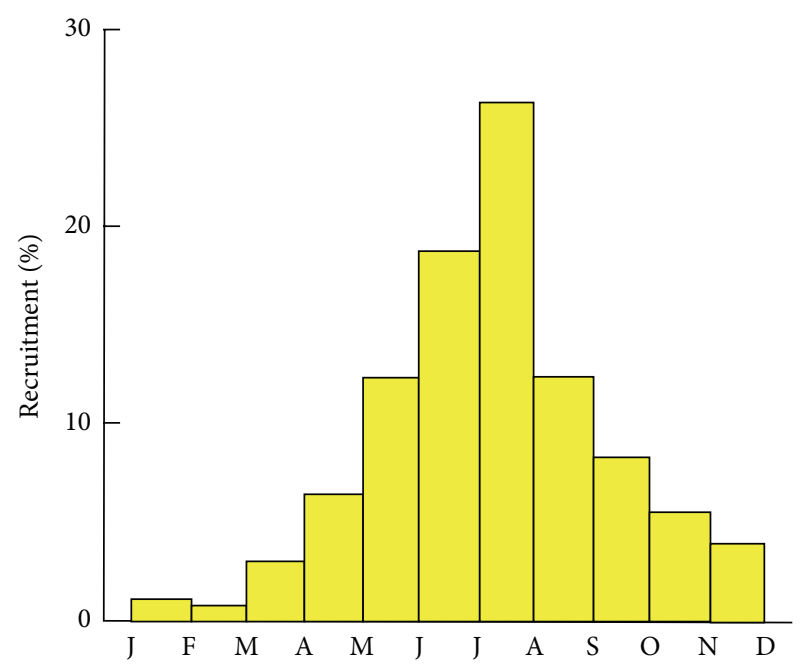

FIGURE 7: Recruitment pattern of horse mackerel. The recruitment pattern showed one annual pulse of recruitment for horse mackerel.

$\left(t_{\max }\right)$ equals $3 / k$, we obtain $t_{\max }$ approximately as 4.7 years, which corresponds not well with other results (based on otolith readings) obtained from Bulgarian coast (Table 1 ). Growth performance index $(\phi=2.406)$ derived for this study is higher than values estimated by others who used otolith readings. When compared with the otholith-based studies, this study shows relatively rapid growth, that is, higher $k$ parameter. The otoliths of T. mediterraneus were difficult to interpret similar to T. trachurus when age determination for older individuals is particularly imprecise [22-26]. However, the otoliths of T. mediterraneus presented problems specific to assigning ages to younger individuals related to interpreting the first true annulus [27]. Misidentification of annual rings may lead to an underestimation of the $k$ parameter and overestimation of $t_{0}$, resulting in lower $\phi$ values [28]. The growth coefficient $(k)$ value from this study was determined to be high (0.64 per year) compared to the low value estimated by other investigations. This may probably be due to high mean annual water temperature in Bulgarian Black Sea waters during the summer, and partly as a result of dominance of 2-year-old fishes in the catches. Sea surface temperature showed cooperatively high values within the framework of $28-31^{\circ} \mathrm{C},[29]$, Table 2. Sudden shifts in temperature can have disastrous effects on fish populations (e.g., thermal stress) [30]. Furthermore, fish growing in different water bodies have different $k$ values. It is observed that $k$ value is higher in young fish (1-year-old), [30]. $M / K$ ratio is the measure of validity of mortality estimate, and it is found to be 1.69 ; it is within the range of 1.5 to 2.5 recommended by [21]. The hypothetical age at which length is zero (to) values was negative. This result compared favorably with the general observation made by [16]. Many growth studies use methods that do not provide realistic estimates of $t_{0}$, particularly in conditions where the sample sizes and ranges are not representative or smaller specimens are absent in the sample [31]. 
TABLE 2: Rate and digression of SST during August, 2010 (after Grozdev and Dimitrova, 2010 [28]).

\begin{tabular}{lccc}
\hline Station & Rate & August, 2010 & Digression \\
\hline Shabla & 21.9 & 27.88 & +5.98 \\
Varna & 22.4 & 28.17 & +5.77 \\
Bourgas & 23.8 & 28.48 & +4.68 \\
\hline
\end{tabular}

\section{References}

[1] St. Stoyanov, Z. Georgiev, L. Ivanov et al., Fishes in Black Sea, State Publishing House, Varna, Bulgaria, 1963.

[2] W. Numann, Biologische Untersuchungen uber die Stocker des Bosphorus, des Schwarzen Meeres und der Marmara, Istanbul University, 1956.

[3] Yu. G. Aleev, Horse Mackerel of the Black Sea, VNIRO Press, 1952.

[4] Yu. G. Aleev, "Horse Mackerel (Trachurus ) of the Soviet Seas," Tr. Sevastopol.Biol. St., vol. 9, pp. 167-212, 1957 (Russian).

[5] Z. M. Georgiev and P. Kolarov, "Abs. Bulletin of Bulgarian Academy of Sciences," 1959.

[6] Z. M. Georgiev and P. Kolarov, "On the migration and distribution of horse mackerel (Trachurus ponticus Aleev) in the western part of Black Sea," Arbeiten des Zentralen Forschungsinstitutes Fur Fishzught und Fisherei Varna, vol. 2, pp. 148-172, 1962.

[7] I. Dobrovolov and S. Dobrovolova, "Biochemical polymorphism of the Black Sea and Mediterranean scads," in Proceedings of the Institute of Oceanography and Fisheries, Varna, vol. 2, pp. 101-107, 1983.

[8] I. Dobrovolov, "Study of population structure of the Black Sea horse mackerel with gene-markers," Tech. Rep., Anniversary National Conference of Biology, Pleven, Bulgaria, 1986.

[9] K. Prodanov, K. Mikhailov, G. Daskalov et al., "General fisheries council for the Mediterranean FAO," Studies and Reviews, vol. 68, pp. 73-81, 1997.

[10] K. Michailov and K. Prodanov, "Commercial fisheries of small pelagic fishes along the Bulgarian Black Sea coast during 19252002," in Proceedings of the International Conference on the Sustainable Development of the Mediterranean and Black Sea Environment, 2003.

[11] L. S. Ivanov and R. J. H. Beverton, The Fisheries Resources of the Mediterranen, Part 2, FAO Studies and Reviews, 1985.

[12] V. Tichonov, "Material knowledge of the large size type of Black Sea Horse Mackerel image life," Tr. Az Cherniro, vol. 16, pp. 177191, 1955 (Russian).

[13] P. O. Abohweyere and E. A. Falaye, "Population parameters of Macrobrachium vollenhovenii in the Lagos-Lekki Lagoon System, Nigeria," Journal of FisheriesInternational, vol. 3, no. 1, pp. 27-33, 2008.

[14] F. C. Gayanilo Jr., P. Sparre, and D. Pauly, The FAOICLARM Stock Assessment Tools (FISAT) User's Guide, vol. 7 of FAO. Computerized Information Series, FAO, Roma, Italy, 1994.

[15] D. Pauly, "Some Simple methods for the assessment of tropical fish Stock," Tech. Rep. 234, FAO Fisheries \& Aquaculture, 1983.

[16] D. Pauly and J. L. Munro, "Once more on the comparison of growth interval in fish and invertebrates," Fishbyte, vol. 2, no. 1, p. 21, 1984.

[17] C. C. Taylor, "Cod growth and temperature," Journal du Conseil Permanent International pour l'Exploration de la Mer, vol. 23, pp. 366-370, 1958.
[18] D. Pauly, "On the interrelationships between natural mortality, growth parameters, and mean environmental temperature in 175 fish stocks," ICES Journal of Marine Science, vol. 39, pp. 175192, 1980.

[19] R. J. H. Beverton and S. J. Holt, On the Dynamics of Exploited Fish Population, vol. 19, The Fisheries Investment, London, UK, 1957.

[20] R. J. H. Beverton and S. J. Holt, "A review ofthe lifespans andmortality rates offish in nature, and their relation to growth andother physiological characteristics," in Ciba Foundation Colloquiumon Ageing, G. E. Wostenholme and M. O’Connor, Eds., pp. 142-180, 1959.

[21] C. T. Macer, "Some aspects of the biology of the horse mackerel [Trachurus trachurus (L.)] in waters around Britain," Journal of Fish Biology, vol. 10, no. 1, pp. 51-62, 1977.

[22] M. Kerstan, "Age, growth, maturity, and mortality estimates of horse mackerel (Trachurus trachurus) from the waters west of Great Britain and Ireland in 1984," Archiv für Fischereiwissenschaft, vol. 36, pp. 115-154, 1985.

[23] A. T. G. W. Eltink and C. Kuiter, "Validation of ageing techniqueson otoliths of horse mackerel (Trachurus trachurusL.)," International Council for the Exploration of the Sea, vol. 43, 15 pages, 1989.

[24] V. Alegría-Hernández, Observations on the Age and Growth of Trachurus trachurus (L.) in the Middle Adriatic, Institute of Oceanography and Fisheries, 1984.

[25] C. Karlou-Riga and A. Sinis, "Age and growth of horse mackerel, Trachurus trachurus (L.), in the Gulf of Saronikos (Greece)," Fisheries Research, vol. 32, no. 2, pp. 157-171, 1997.

[26] C. Karlou-Riga, "Otolith morphology and age and growth of Trachurus mediterraneus (Steindachner) in the Eastern Mediterranean," Fisheries Research, vol. 46, no. 1-3, pp. 69-82, 2000.

[27] H. Özbilgin and C. W. Glass, "Role of learning in mesh penetration behaviour of haddock (Melanogrammus aeglefinus)," ICES Journal of Marine Science, vol. 61, no. 7, pp. 1190-1194, 2004.

[28] D. Grozdev and P. Dimitrova, "Temperature record of sea water of Bulgarian Black Sea coast," http://info.meteo.bg/g120/ ppts/seatemp_DG_PD.ppt.

[29] J. M. Roessig, C. M. Woodley, J. J. Cech, and L. J. Hansen, "Effects of global climate change on marine and estuarine fishes and fisheries," Reviews in Fish Biology and Fisheries, vol. 14, no. 2, pp. 251-275, 2004.

[30] M. Abdulakarim, K. Bununu, and A. Mohammed, "Fish and fisheries of Gubi Dam, Ganjuwa Local Gorvernment Area, Bauchi State," Journal of League of Researchers In Nigeria, vol. 6, no. 2, pp. 1-4, 2005.

[31] V. Raykov and M. Yankova, "Growth dynamics and mortality estimation of the Horse Mackerel (Trachurus mediterraneus ponticus, Aleev) migrating along the Bulgarian Black Sea Coast," in Proceedings of the 1st Biannual Scientific Conference Black Sea Ecosystem and Beyond, pp. 765-778, Istanbul, Turkey, May 2005.

[32] M. Yankova and V. Raykov, "Approximate assessment of the natural mortality rate of the horse mackerel, Trachurus mediterraneus ponticus Aleev in the Bulgarian Black Sea territorial waters," Cercetary Marine INCD.M, vol. 36, pp. 341-348, 2006.

[33] M. Yankova and V. Raykov, "Resent investigation on population structure of Horse mackerel (Trachurus mediterraneus ponticus Aleev., 1956) in the Bulgarian Black Sea coast," Proceedings of the Institute of Fishing Resources Varna, vol. 27, pp. 39-46, 2009.

[34] M. H. Yankova, V. S. Raykov, D. B. Gerdzhikov, and P. B. Frateva, "Growth and length-weight relationships of the horse 
mackerel, Trachurus mediterraneus ponticus (Aleev, 1956), off the Bulgarian Black Sea coast," Turkish Journal of Zoology, vol. 34, no. 1, pp. 85-92, 2010. 

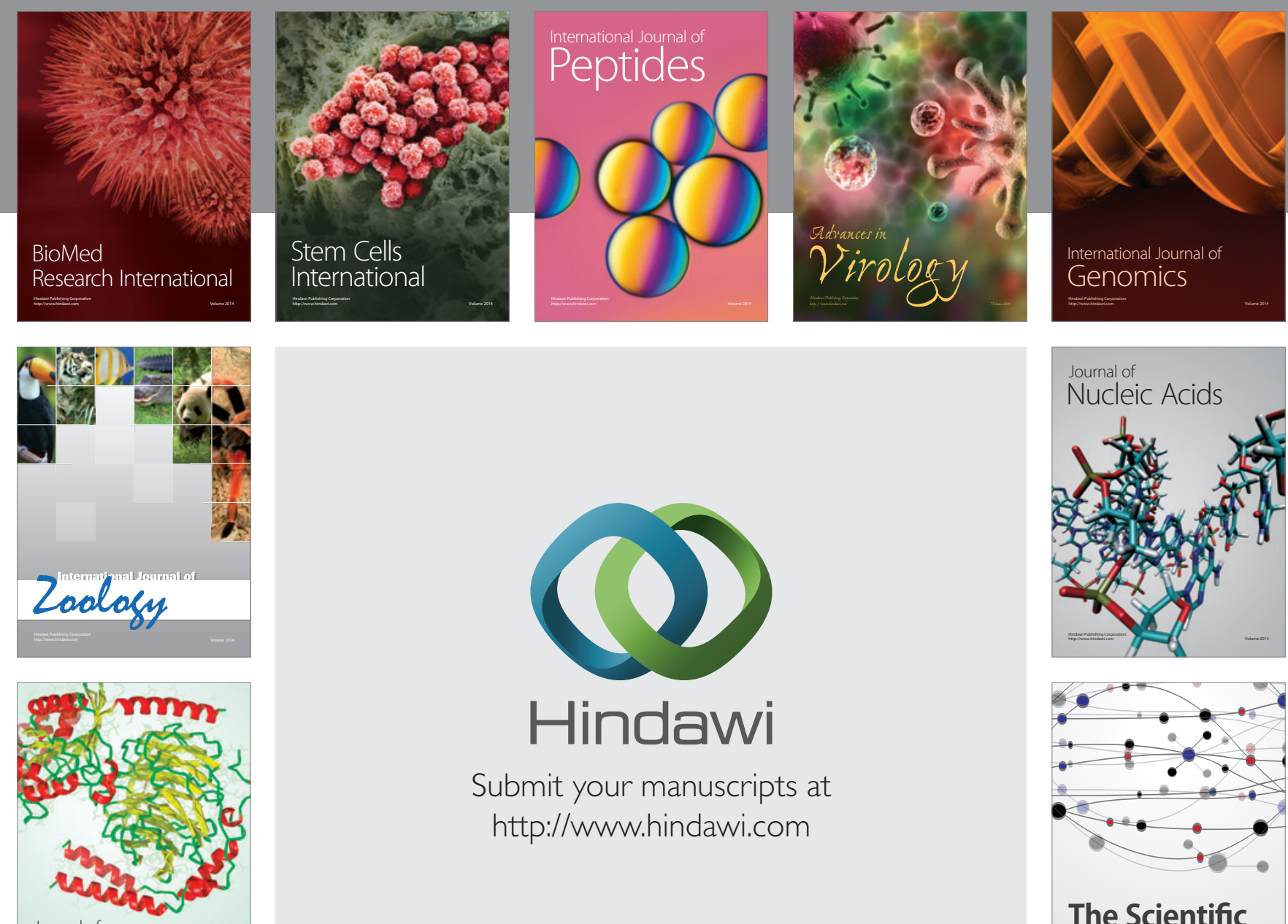

Submit your manuscripts at

http://www.hindawi.com

Journal of
Signal Transduction
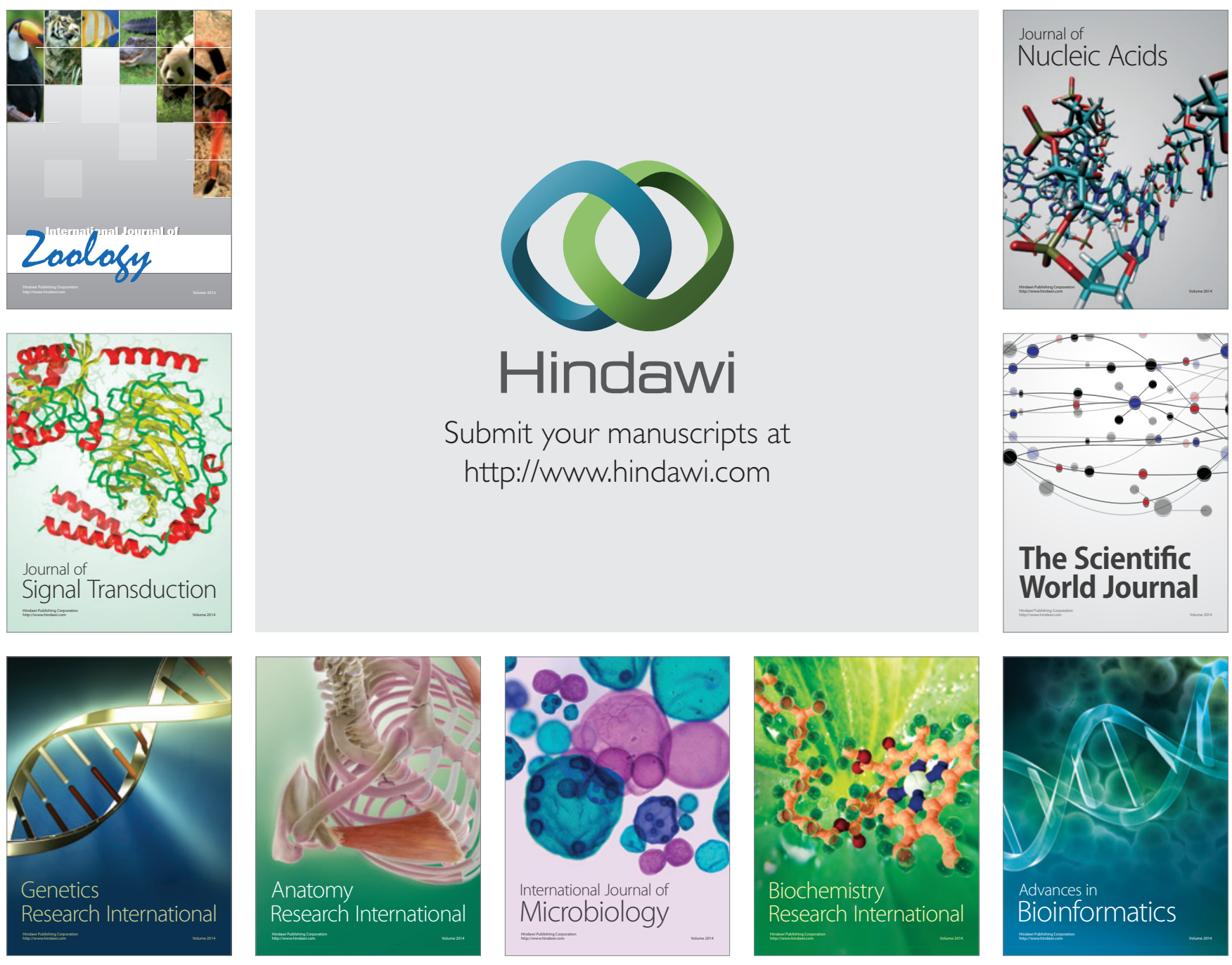

The Scientific World Journal
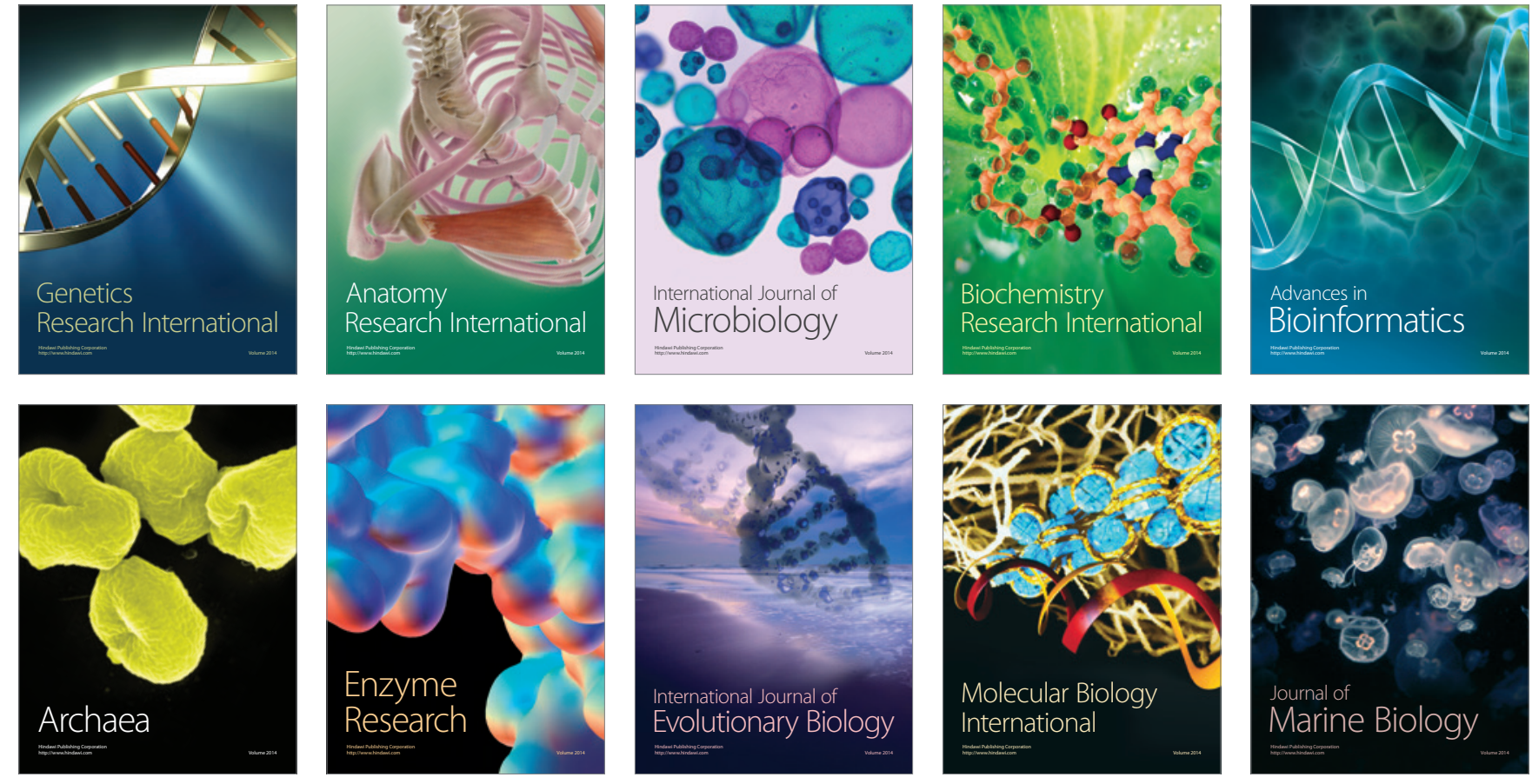